\title{
Instrumental vaginal deliveries at tertiary centre
}

\author{
Shameel Faisal*, Amarjeet Bava, Y. S. Nandanwar
}

Department of Obstetrics and Gynecology, Lokmanya Tilak Municipal Medical College and Lokmanya Tilak Municipal General Hospital, Sion, Mumbai, Maharashtra, India

Received: 17 October 2016

Revised: 23 October 2016

Accepted: 25 October 2016

\section{*Correspondence:}

Dr. Shameel Faisal,

E-mail: shameelfaisal@gmail.com

Copyright: () the author(s), publisher and licensee Medip Academy. This is an open-access article distributed under the terms of the Creative Commons Attribution Non-Commercial License, which permits unrestricted non-commercial use, distribution, and reproduction in any medium, provided the original work is properly cited.

\begin{abstract}
Background: Operative vaginal delivery has been maligned since the days of W. J. Little with the word "Forceps" becoming synonymous with the "Birth Injury" and "Cerebral palsy". Instrumental vaginal deliveries in that era were the end result of a long, obstructed labour performed for maternal benefits and to avoid destructive procedures to the fetus. The aims and objectives of the study were to find out the incidence of instrumental vaginal delivery at our tertiary institute and to know the indications of the procedure and to study the impacts of the same on maternal and fetal outcomes.

Methods: This was as observational prospective cohort study on Instrumental Vaginal Deliveries (IVD) carried out between Jan 2015 to Dec 2015 at a tertiary hospital in Sion, Mumbai. All the patients who had an instrumental vaginal delivery were studied in terms of maternal age, parity, indications for the same, maternal and fetal outcomes, APGAR scoring, NICU admissions and complications in both.

Results: The incidence of Instrumental vaginal delivery was $2.8 \%$ of all deliveries, most of the patients between 20 $30 \mathrm{yrs}(88 \%)$ and maximum primigravida $(57.19 \%)$. In $70.56 \%$ patients it was indicated because of prolonged second stage of labour. 2 patients required blood transfusion, other complications being cervical tear (36 cases) and extension of episiotomy (27 cases). 82 newborn babies had birth asphyxia for which NICU admission was required.

Conclusions: It is evident from our study that Instrumental Vaginal Delivery is an important emergency obstetrics procedure in our obstetrics day to day care. It is very important to make Instrumental Vaginal Delivery procedure available and accessible everywhere especially in low resource country like India where the need is high and caesarean section as alternative is not always available. It should be made available for such patient with abnormal prolonged labour and complication should be identified and managed at the earliest.
\end{abstract}

Keywords: Assisted vaginal delivery, Forceps, Instrumental vaginal delivery, Operative vaginal delivery, Vacuum

\section{INTRODUCTION}

A vaginal delivery accomplished with the help of instruments that can be either Forceps or Vacuum is termed as instrumental vaginal delivery or Operative vaginal delivery or assisted vaginal delivery. ${ }^{1}$

The incidence varies from country to country and even in the same country from one obstetrician to other. In the RCOG Consultant Conference, the instrumental vaginal delivery rate of $10.5 \%$ was reported with a range of 4$20 \%$. The consensus at the conference was to aim to lower the rate to an average of $8.5 \%$ (range $5-15 \%)^{2}$

The incidence of instrumental vaginal delivery in the United States is $4.5 \%$ and that in United Kingdom is between $10 \%-15 \% .^{3}$

Previously worldwide studies were carried out to compare the neonatal and maternal complications 
between forceps and vacuum deliveries. Cochrane Systemic Review of nine Randomised Controlled Trials (RCT) showed that vacuum extractor is no more likely to be associated with APGAR score at 5 min as compared to forceps and some studies have shown maternal complications higher with forceps application. ${ }^{4-6}$

According to the WHO and UN Agencies, Assisted vaginal delivery is one of the six critical functions of basic EMERGENCY Care. ${ }^{7}$ So it's very important to realise the fact that instrumental vaginal delivery procedures should be made available and accessible everywhere especially in low resource countries like India where the need is high and caesarean section as alternative is not always available. ${ }^{5,8,9}$ In response to the growing number of caesarean deliveries and the morbidities associated with the increasing number of caesarean deliveries the ACOG and the Society for Maternal Fetal Medicine recently conducted a workshop in Feb 2012 at Dallas, Texas, US to address the concept of preventing the primary caesarean delivery. ${ }^{10}$

\section{METHODS}

A total of 299 cases were included in the Prospective Observational study carried out from Jan 2015 - Dec 2015.

The indications of instrumental vaginal delivery were broadly based on 4 common indications (summarised in the following Table 8).

After the case selection, written valid and informed consent was obtained, and obstetrics examination performed to confirm fulfilment of criteria for the same.

In our setting, Forceps deliveries were performed by application of the short curved/ Straight Outlet forceps (e.g. Wrigley s Forceps/ Simpsons Forceps).

Vacuum deliveries were performed by application of Silastic cups.

In all the selected cases, immediately after the delivery of the baby, a compulsory per Speculum examination and 3 sponge holders were used at the labour table to look for cervical lacerations, vaginal laceration, Perineal tear, episiotomy extensions or Periurethral tear; intra venous drip of oxytocin were given in all and prostaglandins were administered prophylactically to prevent PPH. All the cases were given intravenous broad spectrum antibiotics for three days. These patients were discharged on day 4 .

Newborn outcome in terms of APGAR scoring at $1 \mathrm{~min}$ and $5 \mathrm{~min}$, convulsions, instrumental injuries or complications (Cephalhematomas, Caput succedaneum, NICU admissions, Jaundice, neonatal sepsis) was noted.

\section{RESULTS}

During the study period there were total of 10,756 deliveries in our institution out of which 299 cases of instrumental vaginal delivery including 296 cases were of Forceps assisted and 3 cases of Vacuum assisted delivery.

Table 1: Incidence of instrumental vaginal delivery (IVD).

\begin{tabular}{|lll|}
$\begin{array}{l}\text { Total number of } \\
\text { deliveries } \\
\text { (Jan 2015 to Dec }\end{array}$ & $\begin{array}{l}\text { Total number of } \\
\text { instrumental } \\
\text { Vaginal delivery }\end{array}$ & $\begin{array}{l}\text { Incidence } \\
\text { (Forceps + } \\
\text { Vacuum) }\end{array}$ \\
\hline 10756 & 299 & $2.77 \%$ \\
\hline
\end{tabular}

Table 2 shows maternal age of the patient. The highest cases of forceps assisted delivery were from the age group of 20 to 25 years. And the lowest were from age group of above 30 years.

Table 2: Maternal age.

\begin{tabular}{|lllll|}
\hline Maternal age & Forceps & Vacuum & Total & $\%$ \\
\hline$<20 \mathrm{yr}$ & 19 & 00 & 19 & 6.35 \\
\hline $20 \mathrm{yr}-25 \mathrm{yr}$ & 158 & 01 & 159 & 53.17 \\
\hline $25 \mathrm{yr}-30 \mathrm{yr}$ & 102 & 02 & 104 & 34.78 \\
\hline$>30 \mathrm{yr}$ & 17 & 00 & 17 & 5.68 \\
\hline Total & 296 & 03 & 299 & \\
\hline
\end{tabular}

Table 3: Parity.

\begin{tabular}{|lllll|}
\hline Parity & Forceps & Vacuum & Total & $\%$ \\
\hline Primigravida & 169 & 2 & 171 & 57.19 \\
\hline Gravida 2 & 73 & 00 & 73 & 24.41 \\
\hline Gravida 3 & 49 & 01 & 50 & 16.38 \\
\hline > Gravida 3 & 05 & 00 & 05 & 1.67 \\
\hline Total & 296 & 03 & 299 & \\
\hline
\end{tabular}

There were $70.56 \%$ of indications of labour in prolonged second stage. In maternal heart disease this indication was $14.38 \%$.

Table 4: Indications for applications.

\begin{tabular}{|lllll|}
\hline Indications & Forceps & Vacuum & Total & $\%$ \\
\hline $\begin{array}{l}\text { Prolonged } \\
\text { second stage } \\
\text { of labour }\end{array}$ & 208 & 03 & 211 & 70.56 \\
\hline $\begin{array}{l}\text { Maternal heart } \\
\text { disease }\end{array}$ & 43 & 00 & 43 & 14.38 \\
\hline $\begin{array}{l}\text { Gestational } \\
\text { diabetes }\end{array}$ & 05 & 00 & 05 & 1.67 \\
\hline Postdatism & 07 & 00 & 07 & 2.34 \\
\hline Fetal distress & 33 & 00 & 33 & 11.03 \\
\hline Total & 296 & 03 & 299 & \\
\hline
\end{tabular}


Table 5: Maternal complications/morbidities.

\begin{tabular}{|lllll|}
\hline Complications & Forceps & Vacuum & Total & $\%$ \\
\hline Cervical tear & 36 & 0 & 36 & 12.04 \\
\hline $\begin{array}{l}\text { Extension of } \\
\text { episiotomy }\end{array}$ & 27 & 00 & 27 & 9.03 \\
\hline Atonic PPH & 12 & 00 & 12 & 4.01 \\
\hline $\begin{array}{l}\text { Excessive blood } \\
\text { loss requiring } \\
\text { blood } \\
\text { transfusion }\end{array}$ & 02 & 00 & 02 & 0.66 \\
\hline $\begin{array}{l}\text { Maternal } \\
\text { mortality }\end{array}$ & 00 & 00 & - & - \\
\hline Ruptured uterus & 00 & 00 & - & - \\
\hline $\begin{array}{l}\text { Broad ligament } \\
\text { injuries }\end{array}$ & 00 & 00 & - & - \\
\hline Traumatic PPH & 02 & 00 & - & - \\
\hline Total & 77 & 00 & 77 & \\
\hline
\end{tabular}

Table 6: Neonatal morbidity and mortality.

\begin{tabular}{|lllll|}
\hline Morbidity & Forceps & Vacuum & Total & $\%$ \\
\hline $\begin{array}{l}\text { Apgar score }>6 \\
\text { at 1min }\end{array}$ & 208 & 03 & 211 & 70.56 \\
\hline $\begin{array}{l}\text { Apgar score }<6 \\
\text { at 1min }\end{array}$ & 82 & 00 & 82 & 27.42 \\
\hline Fresh Still birth & 06 & 00 & 06 & 2.00 \\
\hline Total & 296 & 03 & 299 & \\
\hline
\end{tabular}

Table 7: Newborn complications.

\begin{tabular}{|lllll|}
\hline Complications & Forceps & Vacuum & Total & $\%$ \\
\hline Cephalhematomas & 0 & 1 & 01 & 0.33 \\
\hline Other Injuries & 1 & 0 & 01 & 0.33 \\
\hline Neonatal Jaundice & 19 & 1 & 20 & 6.68 \\
\hline Neonatal sepsis & 0 & 0 & 00 & - \\
\hline $\begin{array}{l}\text { Neonatal } \\
\text { convulsions }\end{array}$ & 2 & 0 & 02 & 0.66 \\
\hline NICU admissions & 82 & 0 & 82 & 27.42 \\
\hline Total & 105 & 1 & 106 & \\
\hline
\end{tabular}

\section{DISCUSSION}

\section{Incidence of instrumental vaginal delivery (IVD)}

During the study period there were total of 10,756 deliveries in our institution out of which 299 cases of instrumental vaginal delivery including 296 cases were of Forceps assisted and 3 cases of Vacuum assisted delivery.

In our study at our institute the incidence of Instrumental vaginal delivery is $2.77 \%$.

It ranges between 10 and $15 \%$ in the UK and $4.5 \%$ in the United States. $^{2}$

It is also very much lower than $8.5 \%$ recommended by RCOG and also lower than developed countries. ${ }^{3}$
However IVDs are underused in low resource settings. ${ }^{3}$

In the study carried out by Nigeria by Aliyu LD et al observed incidence of intrumental vaginal delivery $0.69 \%$. $^{11}$

In low resource the rates of IVD are low, ranging from $1 \%$ or less in Niamey (Niger), Ougadaougou (Burkina Faso) and Bamako (Mali) to $3 \%$ in Nouakchott (Mauritania). ${ }^{12}$

\section{Maternal age}

The above table shows the majority of women were young between 20 to 25 yrs making $53.17 \%$ followed by 25 to 30 yrs making $34.78 \%$.

In the study carried out in United States similar results were observed. ${ }^{13}$

In the study carried out by Nigeria by Aliyu LD et al also observed women upto $25 \mathrm{yr}$ of age forming $62 \%$ of cases. $^{11}$

\section{Parity}

$57.19 \%$ cases were primigravida followed by second gravida with $24.41 \%$ cases.

In the study carried out by Nigeria by Aliyu LD et al also observed primigravida forming $52 \%$ and second gravid $18 \%$ cases. $^{11}$

In a study by Prapas $\mathrm{N}$ et al on Instrumental vaginal delivery also observed primigravida forming $84.75 \%$ and multigravida $15 \%$ cases. $^{14}$

\section{Indications for applications}

We found the most indication for instrument application was the Prolonged second stage of labour (70.56\%) followed by maternal heart disease (14.38\%). Fetal distress accounted for $11 \%$ cases.

In a study by Singh Abha and Rathore reported the indication as fetal distress in $20.83 \%$ and prolonged second stage in $16 \%$ cases. $^{15}$

In a study by Prapas $\mathrm{N}$ et al on Instrumental vaginal delivery observed most common indication as Prolonged second stage of labour in $69.73 \%$ followed by Fetal distress accounting for $26.47 \% .^{14}$

An Operative vaginal delivery should only be performed if there is an appropriate indication.

The American College of Obstetrics and Gynecologists (ACOG) has published guidelines on the use of Operative vaginal delivery aid (both Forceps and vacuum) which 
included a list of accepted indications for such procedures. ${ }^{16}$ They are summarised in the Table 8 below:

Table 8: ACOG indication for the assisted vaginal delivery.

\begin{tabular}{|c|c|}
\hline Indication & Definition / Detail \\
\hline $\begin{array}{l}\text { Prolonged } \\
\text { second stage } \\
\text { of labour }\end{array}$ & $\begin{array}{l}\text { Defined as } \\
\text { In Nulliparous as lack of progress of } \\
\text { labour for } 3 \mathrm{hrs} \text { with regional } \\
\text { anesthesia or } 2 \mathrm{hrs} \text { without anesthesia. } \\
\text { In multiparous as lack of progress of } \\
\text { labour for } 2 \mathrm{hrs} \text { with regional } \\
\text { anesthesia or } 1 \mathrm{hrs} \text { without anesthesia. }\end{array}$ \\
\hline $\begin{array}{l}\text { Non } \\
\text { Reassuring } \\
\text { fetal testing }\end{array}$ & $\begin{array}{l}\text { Suspicion of immediate or potential } \\
\text { fetal compromise is an indication for } \\
\text { the operative vaginal delivery }\end{array}$ \\
\hline $\begin{array}{l}\text { Elective } \\
\text { shortening of } \\
\text { second stage } \\
\text { of labour }\end{array}$ & $\begin{array}{l}\text { In maternal cardiovascular / } \\
\text { neurological disorders }\end{array}$ \\
\hline $\begin{array}{l}\text { Maternal } \\
\text { exhaution }\end{array}$ & $\begin{array}{l}\text { Largely subjective and not well } \\
\text { defined }\end{array}$ \\
\hline
\end{tabular}

\section{Maternal complication / morbidities}

In the our study the maternal complications due to forces applications causing cervical tear and lacerations accounted for $12.04 \%$ followed by cases with episiotomy extension in $9.03 \%$ cases.

Atonic post partum hemorrhage noted in $4 \%$ cases.

However 2 patients had excessive blood loss due to traumatic with cervical laceration which was managed by prostaglandins with suturing and intravenous oxytocin drip. Blood transfusion given in them.

In study by Singh Abha and Rathore the incidence of episiotomy extension was $26.66 \%$. $^{15}$

In the review of over 50000 vaginal deliveries at the University of Miami, the rate of $3^{\text {rd }} / 4^{\text {th }}$ perineal lacerations were significantly higher in forceps $(20 \%)$ and Vacuum (10\%) as compared to the Spontaneous vaginal delivery. ${ }^{17}$

In study by Bradley et al the rate of severe vaginal lacerations was approximately $32 \%$ and that by Handa VL at al showed incidence of vaginal laceration to be between $20-50 \%$. $^{18,19}$

Similar results were also seen in the study by Sultan $\mathrm{AH}$, Kamm MA, Hudson CN Bartram CI. ${ }^{6}$

\section{Neonatal morbidity and mortality}

We have observed that $70.56 \%$ of the newborn with good APGAR score $>6$ at $1 \mathrm{~min}$.
However there were $2 \%$ cases of Fresh still birth noted.

Evidence evaluating neonatal morbidity after instrumental vaginal delivery is inconsistent. ${ }^{20}$

A Cochrane Database systematic review of 10 trials comparing vacuum extraction with forceps delivery found no significant differences in Apgar scores at one and five minutes and few serious injuries in neonates, although the vacuum extractor was associated with an increase in cephalohaematoma and retinal haemorrhage. ${ }^{21}$

Murphy DJ et al in a recent prospective study found that neonatal trauma and fetal acidosis were more common after failed instrumental vaginal delivery than after immediate caesarean section. ${ }^{22}$

\section{Newborn Complications}

82 newborn babies required NICU admission due to birth asphyxia. 20 babies had neonatal Jaundice.

Humerus fracture was noted in one baby following forceps applied for shoulder dystocia. Humerus fracture was managed with the help of orthopaedic surgeons.

In a study by Prapas $\mathrm{N}$ et al on Instrumental vaginal delivery showed $14.43 \%$ newborn required NICU admission. $^{14}$

In our study 2 newborns had convulsions $(0.66 \%)$ and 1 newborn has cephalhematoma $(0.33 \%)$.

\section{CONCLUSION}

In the present study and after studying various recent literatures it can be concluded that the decision to proceed with an operative vaginal delivery when a spontaneous vaginal delivery is not possible must be based upon maternal and fetal risks.

However risk and benefits of both the modes of deliveries (forceps and vacuum) must be individualised in each scenario and operative vaginal deliveries should only be performed if considered a safe alternative.

So it's very important to reinvent the training and use of Operative vaginal delivery so as to optimise this art which is underutilised today. When it is performed by skilled provider it is an ideal alternative to the Ceserean delivery in the chosen patients.

Funding: No funding sources Conflict of interest: None declared

Ethical approval: The study was approved by the Institutional Ethics Committee 


\section{REFERENCES}

1. Ali UA, Norwitz ER. Vacuum assisted vaginal delivery.Rev Obstet Gynecol. 2009;2(1):5-17.

2. Johanson R. Advances in assisted vaginal delivery with vacuum extractor.In Bonnar $\mathrm{J}$ (Ed).Recent Advances in Obstetrics and Gynecology. Edinburg: Churchill Livingstone; 1998;125-139.

3. Ameh CA, Weeks AD. The Role of Instrumental Vaginal delivery in low resource settings; BJOG 2009;116(1):22-5.

4. Johanson RB, Menon BKV, Vacuum extraction versus forceps delivery. (Cochrane Review); In:the Cochrane Library; 1999 Oxford.

5. Aliya I, Aisha HK, Javaria NM. Vacuum and Forceps deliveries; comparisons of maternal and neonatal complications. Profession Med J. 2008;15(1):87-90.

6. Sultan AH, Kamm MA, Bautram CL, Hudson CN. Anal sphincter trauma during Instrumental delivery. Int Obstet Gynecol. 1993;43:263-70.

7. UNICEF, WHO, UNFPA, Guidelines for monitoring the availaibility and use of obstetric services; 1997. NewYork

8. Ogunniyi SO, Sunusu YO. Instrumental vaginal delivery in Ile-Ife and Ilesha, Nigeria. Nig J Med. 1988;7(3):105-8.

9. Eogan M, Herlihy CO. Safe use and enduring value of operative vaginal delivery. The $\mathrm{J}$ of Family practice. 2006;18(6).

10. Spongy CY, Berghella V. Wenstrom KD. Preventing the first ceaserean delivery. Obstet Gynecol. 2012:120:1181-93.

11. Aliyu LD, Kadas AS, Hauwa MA. Instrumental vaginal delivery in bauchi, northeast Nigeria; J West Afr Coll Surg 2011;1(4):18-27. https://www.ncbi.nlm.nih.gov/pmc/journals/2533

12. Bailey PE. The disappearing art of instrumental delivery; Int J of Gyn and Obs. 2005;91:89-96.
13. Demissie K. Rhoads GG, Smulian JC. Operative vaginal delivery, neonatal, infant adverse outcomes: population based retrospective analysis. BMJ. 2004;329-334.

14. Prapas N, Kalogiannidis I, Masoura S. Operative vaginal delivery in singleton term pregnancies: short term maternal and neonatal outcomes. Hippokratia. 2009;13:41-5.

15. Singh A, Rathore P. The J of Obs and Gyn of India. 2011;61(6):663-6.

16. The American College of Obstetricians and Gynecologists (ACOG). Operative vaginal Delivery. Washington DC:ACOG: 2000.

17. Angoli R, Gomez MO, Centuaria G, Sullivan OMJ. Severe Perineal lacerations during vaginal delivery; The University of Miami Experiences. Am J Obstet Gynecol. 2008;182:1083-5.

18. Bradley. Obstet Gynecol. 2013 July;122(1):132-7.

19. Handa VL, Danielsen BH, Gilbert WM. Obstetric anal sphincter lacerations. Obstetr Gynecol. 2001;98:225-30.

20. Patel RR, Murphy DJ. Clinical review Forceps delivery in modern obstetric practice BMJ. 2004;328:1302.

21. Johanson RB, Menon V. Vacuum extraction versus forceps for assisted vaginal delivery. Cochrane Database Syst Rev. 2000;(2):CD000224.

22. Murphy DJ, Liebling RE, Verity L, Swingler R, Patel R. Cohort study of the early maternal and neonatal morbidity associated with operative delivery in the second stage of labour. Lancet. 2001;358:1203-7.

Cite this article as: Shameel F, Bava A, Nandanwar YS. Instrumental vaginal deliveries at tertiary centre. Int J Reprod Contracept Obstet Gynecol 2016:5:4146-50. 